\title{
Occupying the International: Liberal Internationalist Visions and Policy Argumentation in Private International Law
}

Robert Wai

Osgoode Hall Law School of York University, rwai@osgoode.yorku.ca

Source Publication:

Hague Yearbook of International Law. Volume 13 (2000), p. 65-68.

Follow this and additional works at: https://digitalcommons.osgoode.yorku.ca/scholarly_works (c) (1) $(9)$

This work is licensed under a Creative Commons Attribution-Noncommercial-No Derivative Works 4.0 License.

\section{Recommended Citation}

Wai, Robert. "Occupying the International: Liberal Internationalist Visions and Policy Argumentation in Private International Law." Hague Yearbook of International Law 13 (2000): 65-68.

This Article is brought to you for free and open access by the Faculty Scholarship at Osgoode Digital Commons. It has been accepted for inclusion in Articles \& Book Chapters by an authorized administrator of Osgoode Digital Commons. 


\title{
C.2 OCCUPYING THE INTERNATIONAL: LIBERAL INTERNATIONALIST VISIONS AND POLICY ARGUMENTATION IN PRIVATE INTERNATIONAL LAW
}

by

\author{
Robert Wai*
}

\section{Introduction}

The common law regarding the recognition and enforcement of foreign judgments is firmly anchored in the principle of territoriality as interpreted and applied by the English courts in the 19th Century. However, the world has changed since the above principle was developed in 19th Century England. Modern means of travel and communications have made many of the 19th Century concerns appear parochial. The business community operates in a world economy and we correctly speak of a world community even in the face of decentralized political and legal power. Accommodating the flow of wealth, skills and peoples across state lines has now become imperative. Under these circumstances, our approach to the recognition and enforcement of foreign judgments would appear ripe for reappraisal.

Morguard Investments Ltd. v. De Savoye, [1990] 3 S.C.R. p. 1077, at pp. 1095-1096 (Supreme Court of Canada, per La Forest J.)

"[C]oncerns of international comity, respect for the capacities of foreign and transnational tribunals, and sensitivity to the need of the international commercial system for predictability in the resolution of disputes require that we enforce the parties' agreements, even assuming that a contrary result would be forthcoming in a domestic context."

Mitsubishi Motors v. Soler, 473 US 614, 629 (1985) (US Supreme Court, per Blackmun J.)

Discussions of contemporary private international law cannot ignore more general public policy debates concerning law in an era of globalization. There is now an extensive literature - academic and popular - concerning globalization and globalization of law. However, little of that literature has provided a detailed examination of the connections of globalization to regimes of private law. This connection is of interest for at least a couple of reasons. First, it is no longer possible to engage in contemporary debates about private law or private international law without an understanding of the claimed realities and needs of the contemporary international system. Second, those interested in the globalization process more generally may find it useful to consider the particular case and the particular role of private international law in that complex of international

* Assistant Professor, Osgoode Hall Law School, York University, Toronto, Canada. 
changes that are lumped together in the phenomenon known as globalization in law. Internationalist reform in law is a useful place to understand that globalization is at least partly constituted and advanced by social choices, among which are choices reflected in our laws. In turn, decisions about which policies to advance in our laws are at least partly the result of the dominant ideas in the minds of the actors responsible for them - whether they be legislators, judges, litigants, lobbyists, scholars or the populace at large. The incidence of common internationalist policy discourses is something that scholars working in different areas of international and comparative law should analyze and discuss.

\section{The policy discourses of liberal internationalism}

My interest is in the broader policy discourses or, to use Gunther Teubner's term, colliding rationalities, of international economy, international relations and international justice, and their impact on the field of private international law. I argue that internationalist reform in private international law can be usefully viewed as based on three distinct sets of policy objectives about the international: (1) an economic objective of facilitating international trade and transactions, (2) a political objective of increasing interstate co-operation and order, and (3) a moral objective of avoiding parochialism and discrimination. These three general policy objectives - "commerce". "co-operation" and "cosmopolitanism" - are distinct but overlapping, and are thought to generally reinforce each other a common set of programmatic reform objectives. All three can be understood to be policy discourses of "liberal internationalism" because of their origins in the traditions of international liberalism in which the economic, political and normative frameworks were united in a belief in a system of autonomous actors with a potential harmony of interests. In this liberal vision of the international system, autonomous sovereignties are reconciled through the non-controversial benefits of international trade, international co-operation and peace, and cosmopolitan nondiscrimination. This powerful vision of the international order would reconcile efforts by individual states to act in selfish, short-term ways through various systems of norms, institutions and laws, international and national, that would be focused on the long-run co-operative benefits. These policy discourses are perhaps more familiar from their use in the discussions of international trade law and public international law, but I believe that they are having as much impact in the field of private international law.

\section{The impact of internationalist policy vision on private international law}

What impact do these policy frames have for the doctrine of contemporary private international law? Partly, I believe they operate in the background, and help to make sense of, a range of doctrinal reforms that have been occurring in a number of areas of private international law in a number of different jurisdictions. In

rules of jurisdiction, for example, common law courts have encouraged the use 
of forum non conveniens and treaties like the Lugano Convention have taken other steps to rationalize and limit the assumption of jurisdiction. In choice of law, reforms have emphasized party choice in contract and a return to some form of the lex loci delicti in tort. In recognition and enforcement, reforms have limited the grounds for review or refusal of recognition of enforcement of foreign judgments. In arbitration, treaties, legislation and courts have created a broader willingness by courts to enforce arbitration clauses and arbitral awards.

These reforms have occurred in a number of different jurisdictions and via a number of different mechanisms - international treatics, national and state legislation and common law adjudicators. My work argues that a good way to understand these reforms is as motivated by efforts by various actors to promote the economic, political and normative objectives of liberal internationalism. Sometimes the objectives of facilitating international commerce, of promoting international co-operation, or of ensuring cosmopolitan fairness are invoked directly by judges, jurists, legislators, or other policy makers. It is present in the policy work behind conventions such as the Hague and Lugano Conventions on jurisdiction and enforcement of foreign judgments, the Rome Convention on the Law Applicable to Contractual Obligations, and the New York Convention on the Recognition and Enforcement of Foreign Arbitration Awards. Many academic articles and treatises in private international law invoke the need for reform for the purposes of commerce, inter-state co-operation, and cosmopolitan fairness; in particular, scholars working on the use in private international law of interdisciplinary perspectives such as economic analysis (Ronald Brand, Michael Whincop) and game theory (Lea Brilmayer, Larry Kramer) rely heavily on these liberal policy frames.

My particular interest has been in the role of liberal internationalist policy ideals in common law adjudication. Common law judges are fascinating because they are important policy-makers, given that conflict of law largely remains the province of judges in common law jurisdictions, and because common law judges provide a public set of policy justifications for their law-making. Two well known examples are quoted above from the judgment of Blackmun J. in Mitsubishi Motors v. Soler, a leading US Supreme Court judgment favouring enforcement of an arbitration clause even in the presence of antitrust claims, and from $\mathrm{La}$ Forest J. in Morguard Investments Ltd. v. De Savoye, a leading judgment of the Supreme Court of Canada, which liberalized recognition and enforcement of judgments and signalled a radical break towards internationalization and constitutionalization of conflict of laws that was to come in later judgments in private international law in Canada.

Often, doctrinal reforms are justified in terms of intermediate policy values such as certainty and predictability, uniformity and harmonization, comity (deference and respect for foreign law and institutions) and party autonomy and party choice. My contention is that these policy objectives are in turn not ends-inthemselves, but require the support of a vision of the international system in which objectives of maximizing economic benefits, ensuring co-operative relations, and avoiding parochial discrimination are achieved. Similarly, the liberal internationalist vision, if adopted, operate indirectly to impact on the application 
of doctrinal rules to particular cases; facts and laws are interpreted subject to overarching, if often vaguely-defined, values, and the liberal internationalist vision provides a powerful background norm.

\section{The dangers of internationalist policy formalism}

Internationalist legal reform and policy debate frequently adopts a technical, functional and necessitarian approach which fails to acknowledge the degree to which there are a range of alternatives available to societies in how to adapt law to respond to the challenges of contemporary society. Too often what is claimed to be necessary because of global conditions, or to be desirable because of the need to promote "the" international system, is an excuse for partial legal and policy argumentation. My work attempts to illustrate that law reform based on such frameworks can be partial in two respects. First, in a version of Holmes' dictum that general proposition that "General propositions do not decide concrete cases", I argue that general policy objectives of commerce, co-operation and cosmopolitanism usefully identify aspects for consideration, but rarely decide particular substantive disputes in private international law in a determinate way. The same policy objective could be indeterminate as to a number of different kinds of doctrinal reform; in particular, where there is a conflict of interests, none of international commerce. co-operation or cosmopolitanism can choose unique solutions between conflicting interests. A second kind of critique of internationalist policy reasoning in private international law is that internationalist reformers adopt too narrow a view of the appropriate policy objectives for private international law. While the goals of commerce, co-operation and cosmopolitanism are defensible in many respects, they represent only some of a range of worthwhile policy objectives; others include just distribution of benefits and burdens among groups and individuals, the protection of effective political communities and democratic accountability, and the creative value of diversity in alternative legal and policy regimes.

Liberal economic, political and normative frameworks are therefore best viewed as opening up policy dimensions for consideration, rather than necessitating some clear set of legal reforms for all cases. Unfortunately, in practice, internationalist reform based on these structures has not been so open-ended. When placed in the sociological and ideational context of private international law reform, for example, in an era of neo-liberalism or a particular national or professional tradition of liberal internationalism (as I argue exists in Canadian legal circles), the determinacy of liberal policy frames is overstated and the exclusion of alternative policy objectives such as equitable distribution or effective regulation are overlooked. In such a context, the use of critical legal analysis of the structures and then the limits of liberal policy-reasoning are a useful antidote for policy-makers and a useful tool for legal actors seeking to open the terrain of international law to a range of policy concerns that will make globalization in law less of a threat to progressive ends and more of a venue for open contention and debate among different interests and orientations. 